\title{
Need vs. Financing Capability: Human Papillomavirus Vaccinations among Adolescents
}

\author{
Wiwin Lismidiati $^{1 *}$, Ova Emilia ${ }^{2}$, Widyawati Widyawati ${ }^{1}$
}

\begin{abstract}
Background:The incidence of Human Papillomavirus (HPV) infection and cervical cancer in adulthood may be prevented by HPV vaccination in adolescence. Currently, the HPV vaccination coverage rate in developing countries is about $15 \%$. The reason for this low vaccination coverage is most likely due to a lack of information among adolescents and adults. Purpose: To explore adolescents, parents and teachers' needs, obstacles, and expectations around the HPV vaccination. Methods: This research used a qualitative method with a focus group discussion. The research participants were divided into three groups: 21 female students, 17 parents, and 20 teachers. This research was conducted in junior high schools that have programs run by their adolescent reproductive health counseling information centers. The data were analyzed by employing content analysis. Results: HPV vaccination has not been made a priority for adolescents because: 1) There is a lack of available education about HPV and HPV vaccinations for adolescents, parents, and teachers. 2) The high cost for parents to vaccinate their children. 3) Adolescents, parents and teachers believe that the HPV vaccine needs to be administered to adolescents, but they feel that the vaccine is not affordable. Conclusion: It is important to consider a program which will provide accurate information about the HPV vaccination to the community, especially adolescents. Financial management, such as insurance or vaccination savings schemes, may be one way to overcome the problem of the HPV vaccination's cost.
\end{abstract}

Keywords: HPV- cervical cancer- HPV vaccine- knowledge- financing

Asian Pac J Cancer Prev, 20 (10), 2959-2964

\section{Introduction}

The World Health Organization (WHO) states that the Human Papillomavirus (HPV) prophylactic vaccine is highly effective when administered to 16-20 year-old females. The HPV vaccine is expected to prevent up to $70 \%$ of HPV incidence in vaccinated females (WHO, 2006). The HPV vaccination is most effective when administered to 9-13 year-old adolescents, and to 14-26 year-old non-vaccinated people before they have had sexual intercourse. Research shows that if administered in this way, the HPV vaccination may achieve a nearly $90 \%$ protection rate (Cunningham et al., 2015; Gallagher et al., 2018).

In 34 low- and low- to middle-income countries, the vaccination program is supported by the Global Alliance for Vaccines and Immunizations (GAVI). From 2013 to 2016, GAVI provided support to more than 20 countries eligible for a 2-year HPV vaccine demonstration project. In $2014,1.2 \%$ of $10-14$ year-old adolescents were expected to have had at least one dose of the vaccine administered (Bruni et al., 2014; Gallagher et al., 2018).

In Indonesia, the HPV vaccine is available and is recommended by the Indonesian Pediatric Society.
However, at the national level, the administration of the HPV vaccination is still in its initiation process. The HPV vaccination is administered to female students in grades five (first dosage) and six (second dosage) at elementary schools through the School Children's Immunization Month (BIAS) program (Arifah et al., 2017).

Low- to middle-income countries face some constraints in introducing the HPV vaccination to their people. These challenges include: historical/structural factors; programmed vaccinations; and delivery constraints (Gallagher et al., 2018). Other constraints found include socio-cultural, health system, political, and financial factors (Wigle et al., 2013).

In Indonesia, constraints include the parents' acceptance of the HPV vaccinations, the vaccine's cost, the fear of side effects, the preferred location for HPV vaccination (Jaspers et al., 2011), the lack of access to service centers with adequate laboratory and health workers, and the requirement for repeated visits to the service center (Karneli et al., 2013). In addition, a lack of knowledge about the HPV vaccination, the vaccine's safety, side effect considerations, and not being recommended by physicians or health workers are some of the other challenges found around the HPV vaccination's administration (Arifah et 
al., 2017).

The research question is what are the needs, challenges and expectations of female students, parents and teachers for the HPV vaccination program?

\section{Materials and Methods}

This qualitative research took place in junior high schools in Bantul and Sleman under the Adolescent Reproductive Health Counseling Information program in Yogyakarta Special Region.

\section{Study design and sample}

This focus group discussion was carried out from December 2017 to January 2018. The research design was qualitative using focus group discussion approach. This research sample consists of three groups: female junior high school students, parents, and teachers. The inclusion and exclusion criteria for the female students' group included female students in grades seven and eight who were willing to be participants and who signed the informed consent form; the inclusion and exclusion criteria for the parents' group included the parents of female junior high school students in grades seven and eight who were willing to be participants, and the inclusion and exclusion criteria of the teachers'group included female teachers who were actively teaching subjects during the research period and willing to be respondents.

The teachers' group included teachers who teach school subjects and counseling teachers who have the important role of helping female students at school on a daily basis. Ten teachers were invited to the discussion from each school, and all of them were permitted to attend the discussions. Ten to 12 female students were invited from each school to the Focus Group Discussion (FGD); in all, 10 female students were present from Junior High School A and 11 female students were present from Junior High School B. The parents' group was sampled using the criteria of those with female children in grades seven and eight at the same schools. 10 to 12 parents were invited from each school; six parents were present during the FGD activity from Junior High School A and 11 parents were present from Junior High School B.

\section{Data collection}

The FGD groups met in the same place as their respective schools. The FGDs were conducted in classrooms and laboratory rooms in the respective schools, and lasted for 60-90 minutes. Before starting the group discussions, the purpose of the FGD was explained to the participants and they were asked to provide their written consent through an informed consent form. The participants were told that any data would be kept confidential and that answer anonymity would be maintained. Each discussion group was led by one research facilitator, and an assistant was assigned to take notes and help manage the group. The group discussions were digitally recorded with the permission of the participants.

The research instruments included prepared FGD instructions. The FGD instructions were arranged by the researcher pursuant to previous theories and related research studies. The FGD instructions contained some open-ended questions that were adapted to each discussion group. This research was approved by the Medical and Health Research Ethical Committee under number KE/ FK/1100/EC/2017.

\section{Data analysis}

The recording of each discussion was transcribed by the researcher. The written notes made by the research assistant were added to the record. The research data were analyzed manually with the following qualitative research measures: 1) Transcribing the data collected from the FGDs and making notes during the data's collection about data related to the informants. 2) Reconfirming the accuracy of the data with the participants and triangulating the data with the community health center officer in charge of the local junior high schools health units. 3) Reading all the data or transcripts for general ideas presented by the informants and any other necessary information. 4) Starting coding. 5) Using the coding process's results to develop the theme for further analysis. 6) Presenting the description and theme in a qualitative narration. 7) Interpreting the data.

The themes were analyzed for each question during the FGD sessions with the three participant groups.

\section{Results}

There were 58 participants of the FGDs: 21 female students, 17 parents, and 20 teachers. The participants' characteristics can be seen in Table 1 .

There were five themes namely: (1) Lack of understanding about human papillomavirus vaccine; (2) Difficult to explain to children and make embarrassment are the constrain arise in the health education; (3) Parents'limited funds for children's human papilloma virus vaccination; (4) Insurance covering, discount and savings is the effort that parent's thought to solve financial problems; (5) The constrain in female vaccine are expensive, low economy, not priority in household budget.

Theme 1: Lack of understanding about human papillomavirus and the human papillomavirus vaccine

Fifty of participants expected that adolescents would receive the HPV vaccinations, considering the future effects of exposure to HPV infection. However, most of the participants lacked knowledge about HPV, cervical cancer, and the HPV vaccine. Some participants identified the importance of health education and health promotion with regard to HPV and the HPV vaccine. They stated that they wanted adequate information about HPV, cervical cancer, and the HPV vaccine.

Parent Participant (PP12): "I agree on socialization, but parents must be involved."

Adolescent Participant (AP7): "Socialization at school to provide information of reproductive health and teenager relationship"

Teacher Participant (TP1): "Maybe the knowledge should be prioritized, since it must be a process, not something instant. Children's source of funding is from 
Table 1. Characteristic of Adolescent'Participants

\begin{tabular}{|c|c|c|}
\hline $\begin{array}{l}\text { Adolescent } \\
\text { Partisipant }\end{array}$ & Age & Characteristic \\
\hline AP 1 & $\begin{array}{l}13 \text { years } \\
\text { old }\end{array}$ & $\begin{array}{l}\text { Eight grade junior high female students in } \\
\text { Srandakan Bantul }\end{array}$ \\
\hline AP 2 & $\begin{array}{l}12 \text { years } \\
\text { old }\end{array}$ & $\begin{array}{l}\text { Seventh grade junior high female students } \\
\text { in Srandakan Bantul }\end{array}$ \\
\hline AP 3 & $\begin{array}{l}13 \text { years } \\
\text { old }\end{array}$ & $\begin{array}{l}\text { Eight grade junior high female students in } \\
\text { Srandakan Bantul }\end{array}$ \\
\hline AP 4 & $\begin{array}{l}12 \text { years } \\
\text { old }\end{array}$ & $\begin{array}{l}\text { Seventh grade junior high female students } \\
\text { in Srandakan Bantul }\end{array}$ \\
\hline AP 5 & $\begin{array}{l}13 \text { years } \\
\text { old }\end{array}$ & $\begin{array}{l}\text { Eight grade junior high female students in } \\
\text { Srandakan Bantul }\end{array}$ \\
\hline AP 6 & $\begin{array}{l}13 \text { years } \\
\text { old }\end{array}$ & $\begin{array}{l}\text { Eight grade junior high female students in } \\
\text { Srandakan Bantul }\end{array}$ \\
\hline AP 7 & $\begin{array}{l}14 \text { years } \\
\text { old }\end{array}$ & $\begin{array}{l}\text { junior high female students in } \\
\text { Santul }\end{array}$ \\
\hline AP 8 & $\begin{array}{l}12 \text { years } \\
\text { old }\end{array}$ & $\begin{array}{l}\text { Eight grade junior high female students in } \\
\text { Srandakan Bantul }\end{array}$ \\
\hline AP 9 & $\begin{array}{l}12 \text { years } \\
\text { old }\end{array}$ & $\begin{array}{l}\text { Seventh grade junior high female students } \\
\text { in Srandakan Bantul }\end{array}$ \\
\hline AP 10 & $\begin{array}{l}13 \text { years } \\
\text { old }\end{array}$ & $\begin{array}{l}\text { Eight grade junior high female students in } \\
\text { Srandakan Bantul }\end{array}$ \\
\hline AP 11 & $\begin{array}{l}14 \text { years } \\
\text { old }\end{array}$ & $\begin{array}{l}\text { Eight grade junior high female students } \\
\text { in Ngaglik Sleman }\end{array}$ \\
\hline AP 12 & $\begin{array}{l}13 \text { years } \\
\text { old }\end{array}$ & $\begin{array}{l}\text { Eight grade junior high female students in } \\
\text { Ngaglik Sleman }\end{array}$ \\
\hline AP 13 & $\begin{array}{l}14 \text { years } \\
\text { old }\end{array}$ & $\begin{array}{l}\text { Eight grade junior high female students in } \\
\text { Ngaglik Sleman }\end{array}$ \\
\hline AP 14 & $\begin{array}{l}14 \text { years } \\
\text { old }\end{array}$ & $\begin{array}{l}\text { Eight grade junior high female students in } \\
\text { Ngaglik Sleman }\end{array}$ \\
\hline AP 15 & $\begin{array}{l}13 \text { years } \\
\text { old }\end{array}$ & $\begin{array}{l}\text { Eight grade junior high female students in } \\
\text { Ngaglik Sleman }\end{array}$ \\
\hline AP 16 & $\begin{array}{l}13 \text { years } \\
\text { old }\end{array}$ & $\begin{array}{l}\text { Eight grade junior high female students in } \\
\text { Ngaglik Sleman }\end{array}$ \\
\hline AP 17 & $\begin{array}{l}13 \text { years } \\
\text { old }\end{array}$ & $\begin{array}{l}\text { Eight grade junior high female students in } \\
\text { Ngaglik Sleman }\end{array}$ \\
\hline AP 18 & $\begin{array}{l}14 \text { years } \\
\text { old }\end{array}$ & $\begin{array}{l}\text { Eight grade junior high female students in } \\
\text { Ngaglik Sleman }\end{array}$ \\
\hline AP 19 & $\begin{array}{l}14 \text { years } \\
\text { old }\end{array}$ & $\begin{array}{l}\text { Eight grade junior high female students in } \\
\text { Ngaglik Sleman }\end{array}$ \\
\hline AP 20 & $\begin{array}{l}13 \text { years } \\
\text { old }\end{array}$ & $\begin{array}{l}\text { Eight grade junior high female students in } \\
\text { Ngaglik Sleman }\end{array}$ \\
\hline PS 21 & $\begin{array}{l}13 \text { years } \\
\text { old }\end{array}$ & $\begin{array}{l}\text { Eight grade junior high female students in } \\
\text { Ngaglik Sleman }\end{array}$ \\
\hline
\end{tabular}

their parents. When the parents have no understanding or knowledge of its benefits, it will be hard."

Teacher Participant (TP13): It (socialization) is also needed, but through the biology subject, during the study of reproduction."

Theme 2: Difficult to explain to children and make embarrassment are the constrain arise in the health education

Parent Participant (PP9): "How to communicate, how to talk about it? Will they understand?"

Parent Participant (PP10): "No courage to explain it, since the children cannot understand what we tell them."

Teacher Participant (TP11): "Anything related to female matters is an embarrassment, even if it is a free check-up. The children will also get embarrassed."
Table 2. Characteristic of Parents' Participants

\begin{tabular}{|c|c|c|}
\hline $\begin{array}{l}\text { Parents } \\
\text { Participant }\end{array}$ & Age & Keterangan \\
\hline PP1 & $\begin{array}{l}42 \\
\text { years }\end{array}$ & $\begin{array}{l}\text { Mothers of seventh grade junior high female } \\
\text { students in Srandakan Bantul. She is an } \\
\text { employed. Educational background was senior } \\
\text { high school. }\end{array}$ \\
\hline PP 2 & $\begin{array}{l}37 \\
\text { years }\end{array}$ & $\begin{array}{l}\text { Mothers of eight grade junior high female } \\
\text { students in Srandakan Bantul. She is self } \\
\text { employed. Educational background was senior } \\
\text { high school. }\end{array}$ \\
\hline PP 3 & $\begin{array}{l}37 \\
\text { years }\end{array}$ & $\begin{array}{l}\text { Mothers of seventh grade junior high female } \\
\text { students in Srandakan Bantul. She is an } \\
\text { employed. Educational background was junior } \\
\text { high school. }\end{array}$ \\
\hline PP 4 & $\begin{array}{l}45 \\
\text { years }\end{array}$ & $\begin{array}{l}\text { Mothers of eight grade junior high female } \\
\text { students in Srandakan Bantul. She is self } \\
\text { employed. Educational background was bachelor. }\end{array}$ \\
\hline PP 5 & $\begin{array}{l}41 \\
\text { years }\end{array}$ & $\begin{array}{l}\text { Mothers of seventh grade junior high female } \\
\text { students in Srandakan Bantul. She is in private } \\
\text { sector. Educational background was senior high } \\
\text { school. }\end{array}$ \\
\hline PP 6 & $\begin{array}{l}47 \\
\text { years }\end{array}$ & $\begin{array}{l}\text { Mothers of eight grade junior high female } \\
\text { students in Srandakan Bantul. She is self } \\
\text { employed. Educational background was senior } \\
\text { high school. }\end{array}$ \\
\hline PP 7 & $\begin{array}{l}38 \\
\text { years }\end{array}$ & $\begin{array}{l}\text { Mothers of eight grade junior high female } \\
\text { students in Ngaglik Sleman. She is in private } \\
\text { sector. Educational background was senior high } \\
\text { school. }\end{array}$ \\
\hline PP 8 & $\begin{array}{l}45 \\
\text { years }\end{array}$ & $\begin{array}{l}\text { Mothers of eight grade junior high female } \\
\text { students in Srandakan Bantul. She is an } \\
\text { employed. Educational background was senior } \\
\text { high school. }\end{array}$ \\
\hline PP 9 & $\begin{array}{l}39 \\
\text { years }\end{array}$ & $\begin{array}{l}\text { Mothers of eight grade junior high female } \\
\text { students in Ngaglik Sleman. She is an employed. } \\
\text { Educational background was senior high school. }\end{array}$ \\
\hline PP 10 & $\begin{array}{l}40 \\
\text { years }\end{array}$ & $\begin{array}{l}\text { Mothers of eight grade junior high female } \\
\text { students in Ngaglik Sleman. She is an employed. } \\
\text {. Educational background was senior high } \\
\text { school. }\end{array}$ \\
\hline PP 11 & $\begin{array}{l}38 \\
\text { years }\end{array}$ & $\begin{array}{l}\text { Mothers of eight grade junior high female } \\
\text { students in Ngaglik Sleman. She is self } \\
\text { employed. Educational background was } \\
\text { Diploma. }\end{array}$ \\
\hline PP 12 & $\begin{array}{l}37 \\
\text { years }\end{array}$ & $\begin{array}{l}\text { Mothers of eight grade junior high female } \\
\text { students in Ngaglik Sleman. She is an employed. } \\
\text { Educational background was Diploma. }\end{array}$ \\
\hline PP 13 & $\begin{array}{l}46 \\
\text { years }\end{array}$ & $\begin{array}{l}\text { Mothers of eight grade junior high female } \\
\text { students in Ngaglik Sleman. She is self } \\
\text { employed. Educational background was senior } \\
\text { high school. }\end{array}$ \\
\hline PP 14 & $\begin{array}{l}39 \\
\text { years }\end{array}$ & $\begin{array}{l}\text { Mothers of eight grade junior high female } \\
\text { students in Ngaglik Sleman. She is an employed. } \\
\text { Educational background was vocational school. }\end{array}$ \\
\hline PP 15 & $\begin{array}{l}39 \\
\text { years }\end{array}$ & $\begin{array}{l}\text { Mothers of eight grade junior high female } \\
\text { students in Ngaglik Sleman. She is an employed. } \\
\text { Educational background was vocational school. }\end{array}$ \\
\hline PP 16 & $\begin{array}{l}44 \\
\text { years }\end{array}$ & $\begin{array}{l}\text { Mothers of eight grade junior high female } \\
\text { students in Ngaglik Sleman. She is in private } \\
\text { sector. Educational background was vocational } \\
\text { school }\end{array}$ \\
\hline PP 17 & $\begin{array}{l}40 \\
\text { years }\end{array}$ & $\begin{array}{l}\text { Mothers of eight grade junior high female } \\
\text { students in Ngaglik Sleman. She is an employed. } \\
\text { Educational background was Diploma. }\end{array}$ \\
\hline
\end{tabular}

Teacher Participant (TP12): "Lack of awareness and thinking that everything is alright."

Theme 3: Parents' limited funds for children's human 
Table 3. Characteristic of Teachers'Participant

\begin{tabular}{|c|c|c|}
\hline $\begin{array}{l}\text { Teacher } \\
\text { Participants }\end{array}$ & Usia & Keterangan \\
\hline TP 1 & 43 years & $\begin{array}{l}\text { Math at junior high school teacher in } \\
\text { Srandakan Bantul }\end{array}$ \\
\hline TP 2 & 44 years & $\begin{array}{l}\text { Civilization Education at junior high } \\
\text { school teacher in Srandakan, Bantul }\end{array}$ \\
\hline TP 3 & 42 years & $\begin{array}{l}\text { Biology at junior high school teacher } \\
\text { in Srandakan, Bantul }\end{array}$ \\
\hline ТР 4 & 47 years & $\begin{array}{l}\text { Math at junior high school teacher in } \\
\text { Srandakan Bantul }\end{array}$ \\
\hline TP 5 & 45 years & $\begin{array}{l}\text { Social science at junior high school } \\
\text { teacher in Srandakan Bantul }\end{array}$ \\
\hline TP 6 & 46 years & $\begin{array}{l}\text { Guidance counselor at junior high } \\
\text { school teachers in Srandakan Bantul }\end{array}$ \\
\hline TP 7 & 46 years & $\begin{array}{l}\text { Social science at junior high school } \\
\text { teacher in Srandakan Bantul }\end{array}$ \\
\hline TP 8 & 43 years & $\begin{array}{l}\text { Civilization Education at junior high } \\
\text { school teacher in Srandakan, Bantul }\end{array}$ \\
\hline ТР 9 & 46 years & $\begin{array}{l}\text { Math at junior high school teacher in } \\
\text { Srandakan Bantul }\end{array}$ \\
\hline TP 10 & 46 years & $\begin{array}{l}\text { Guidance counselor at junior high } \\
\text { school teachers in Srandakan Bantul }\end{array}$ \\
\hline TP 11 & 44 years & $\begin{array}{l}\text { Math at junior high school teacher in } \\
\text { Ngaglik Sleman }\end{array}$ \\
\hline TP 12 & 45 years & $\begin{array}{l}\text { Gym at junior high scholl teacher in } \\
\text { Ngaglik Sleman }\end{array}$ \\
\hline TP 13 & 46 years & $\begin{array}{l}\text { Civilization Education at junior high } \\
\text { school teacher in Ngaglik Sleman }\end{array}$ \\
\hline TP 14 & 43 years & $\begin{array}{l}\text { Physics at junior high school teacher } \\
\text { in Ngaglik Sleman }\end{array}$ \\
\hline TP 15 & 44 years & $\begin{array}{l}\text { Biology at junior high school teacher } \\
\text { in Ngaglik Sleman }\end{array}$ \\
\hline TP 16 & 43 years & $\begin{array}{l}\text { Physics at junior high scholl teacher } \\
\text { in Ngaglik Sleman }\end{array}$ \\
\hline TP 17 & 44 years & $\begin{array}{l}\text { Gym at junior high scholl teacher in } \\
\text { Ngaglik Sleman }\end{array}$ \\
\hline TP 18 & 45 years & $\begin{array}{l}\text { Biology at junior high school teacher } \\
\text { in Ngaglik Sleman }\end{array}$ \\
\hline ТP 19 & 44 years & $\begin{array}{l}\text { Social science at junior high school } \\
\text { teacher in Ngaglik Sleman }\end{array}$ \\
\hline TP 20 & 46 years & $\begin{array}{l}\text { Physics at junior high school teacher } \\
\text { in Ngaglik Sleman }\end{array}$ \\
\hline
\end{tabular}

\section{papillomavirus vaccination}

Almost all the participants of the three groups disclosed constraints to buying the human papillomavirus vaccine. Most of them stated that even if many people wanted to buy the HPV vaccine for their daughters, they were unable to buy it because it is expensive. The parents' group disclosed that the vaccine could be included in health insurance plans like the Social Insurance Administration Body (BPJS), which is an important factor in increasing the HPV vaccine's acceptance. Some parent participants stated that the vaccine should not be expensive or there should be a discount for the HPV vaccine's purchase.

Theme 4: Insurance covering, discount and saving is the effort that parent needed to solve financial problems were identified, as follows:

Parent Participant (PP18): "Is it covered by the government's BPJS? Or is it covered by Jamkesda
(Regional Health Insurance) or Jamkesmas (Social Health Insurance)?"

Parent Participant (PP12): "There is normally a discount, for example, buy two get one free."

Adolescent Participant (AP11): "Yes, may be after saving for it."

Teacher Participant (TP9): "Create a program at school which may be budgeted next year."

Theme 5: The constrain in female adolescent vaccine are expensive, low economy, not priority in house hold budget

Parent Participant (PP1/PP6): "The objection is about the high cost. I think it is too much for us in the village. We are in the village, and thus it is too expensive"

Teacher Participant (TP10) : "Parents are of a low economic status, from the perspective of their education and employment, 50\% have a weak economy."

Adolescent Participant (AP7): "There are still many necessities for school tasks."

\section{Discussion}

Adolescents, parents, and teachers have limited knowledge about HPV, cervical cancer, and the HPV vaccine; thus, the need for health education and the socialization of HPV, cervical cancer, and the HPV vaccine is an important factor in changing behavior toward the HPV vaccination. Not much progress has been made by Indonesian health workers with the socialization of $\mathrm{HPV}$, and getting people to have the HPV vaccine to prevent cervical cancer. This is confirmed by the results of an interview with a community health center worker, who stated that the HPV vaccine is not a priority program and that it is not the community health center's policy to socialize it in the adolescent reproductive health concern (PKPR) program. Currently, the PKPR program at community health centers only socializes the issues of older marital age, an early introduction to sex, and adolescent anemia. The lack of recommendations by health workers when socializing the HPV vaccine was also found by Cartmell et al., 2018, which stated that factors contributing to the lack of information provided about the HPV vaccine include: 1) The lack of awareness among some pediatricians and general practitioners about the HPV vaccine directive. 2) Service providers are uncomfortable discussing the topic. Other researchers state that the reason for the lack of parents' knowledge about HPV and the HPV vaccination, as well as for the parents' concern about the side effects, is that there is no recommendation for it by health workers (Morales-Campos et al., 2013; Fernández et al., 2014; Masika et al., 2015). This is confirmed by previous research studies (Reiter et al., 2011; Bartolini et al.,2012) proposing that health workers and teachers are credible sources of information who could provide significant support for an HPV vaccination campaign. Recommendations from physicians is the consistent key predictor of the HPV vaccine's acceptance (Rosenthal et al., 2011).

In Indonesia, parents have a low level of knowledge about HPV, the HPV vaccination, and cervical cancer topics in general (Jaspers et al., 2011). Only about 
$16.6 \%$ of parents have heard about HPV; about $15.8 \%$ have heard of the HPV vaccine; and more than $40 \%$ lack understanding about HPV, the HPV vaccination, and cervical cancer. This percentage is nearly equal to that found in Malaysia and Singapore. There, $12.2 \%$ and 20.0\% (respectively) have heard about HPV, and 10.5\% and $15.8 \%$ (respectively) have heard about the HPV vaccine (Jaspers et al., 2011; Sam et al., 2009). According to these research results, we can conclude that greater information is needed about HPV, cervical cancer, and HPV vaccine topics, considering that the knowledge levels are still low.

This is also confirmed by research (Dempsey and Zimet, 2015; Degarege et al., 2018) stating that health education programs should target the parents and extended family members, so as to increase the coverage rate for future vaccination programs. Parental and school involvement strategies are also an important factor for improving the school vaccination program for adolescents (Whelan et al., 2014).

In this research, both the parents' and teachers' groups stated that they face constraints in providing their daughters with education about sexual matters. The cultural/taboo factor prevents them from providing adolescents with sexual information. Reproductive and sexual health education is a sensitive topic, which needs advocacy to allow it to be provided to young people and the general public. So far, sexual and reproductive health education in schools is incomprehensive and not relevant to the actual sexual behavior and risks adolescents face. This implies the students have limited knowledge about reproductive health in general. Sexual and reproductive health education provided in schools tends to see adolescent reproductive and sexual health issues as merely biological phenomena, and often considers adolescent sexuality as something taboo and dangerous, which should be controlled through moral and religious discourse instead of education (Pakasi and Kartikawati, 2013). The results of the research conducted by Francis et al., (2011) also state that cultural norms and gender form the clearest response with regard to sexual health issues in communications about sexuality between mothers and children.

The results of this research also identify constraints in financing for the HPV vaccination. The high price of the vaccination, combined with no recommendation for it from physicians, is the most influential factor in the HPV vaccination's acceptance. Most of the respondents are from the middle to lower socio-economic groups. Reproductive health savings for the HPV vaccinations' financing is an alternative method for increasing the HPV vaccination's coverage in schools. The research results also show that the three groups of female students, parents, and teachers expect the HPV vaccination program to be free. If the program was free, the HPV vaccination coverage rate would be higher. The triangulation result with health workers states that the community health centers' current program for cervical cancer prevention is still in its early stages, with Visual Inspection with Acetic Acid (VIA) examinations, and there is no socialization of the HPV vaccine as yet. The reason for this is that the program and activity have not yet been included in the regional regulations.

The Minister of Health (2016) stated that the HPV vaccine has just been initiated as part of the government's national program, but it is not a national program for vaccination, so the HPV vaccination's cost is still high. The government's currently prioritized measure is to mobilize resources to strengthen the health system and buy the HPV vaccine. Indonesia has not taken innovative measures, in terms of financing, for introducing the HPV vaccination. Meanwhile, Malaysia has included the HPV vaccine as a priority in its adolescent program, through its school health program (Ezat and Syed, 2011).

One main constraint causing parents not to accept the administration of the HPV vaccine in Indonesia is the cost. The HPV vaccination's cost is not affordable for most Indonesians. The people believe that the government should either fund the vaccination or there should be joint funding between the government and parents for the HPV vaccinations (Arifah et al., 2017; Jaspers et al., 2011; Karneli et al., 2013).

Education about HPV, cervical cancer, and the HPV vaccine is recommended as necessary for adolescents, parents, and teachers. The results of research into the parent and teacher groups states that HPV, cervical cancer and HPV vaccine education should also be provided by involving parents. Parental involvement, through meetings at school, is required since parents make the decisions about their children's vaccinations. Parental involvement in school meetings is an important strategy to educate about HPV, cervical cancer, and the HPV vaccination (Remes et al., 2012). It is important to focus on improving the overall level of knowledge. Similarly, consideration should be made for an alternative to the HPV vaccination's financing, such as an adolescent reproductive health savings scheme, in order to maximize the HPV vaccination's coverage rate.

\section{Acknowledgements}

We would like to acknowledge the staff of the Nursing Department, Faculty of Medicine, Public Health and Nursing, Universitas Gadjah Mada. We thank the study participants for taking time to complete the interview and the school staff for their assistance in conducting this study. Last but not least, we would like to give our highest appreciation to Ibu Vania as the editor of this manuscript.

\section{Funding Statement:}

Funding for this publication was provided by the Ministry of Research, Technology and Higher Education. The funder had no role in the study's design, data collection, analysis, interpretation or publication of the report.

\section{References}

Arifah K, Damayanti W, Sitaresmi MN (2017). Human papillomavirus acceptability among female adolescents in Yogyakarta. Sari Pediatri, 18, 430-5.

Bartolini RM, Winkler JL, Penny ME, Lamontagne DS (2012). Parental acceptance of human papillomavirus in Peru: A 
decision framework. PLoS One, 7, 1-8.

Bruni L, Albero G, Serrano B, et al (2014). Human papillomavirus and related diseases report in the world.ICO/IARCHPV Information Centre, pp 8-23.

Cartmell KB, Youngpierce J, Mcgue S, et al (2018). Barriers, facilitators, and potential strategies for increasing human papillomavirus vaccination: a statewide assessment to inform action. $P V R, \mathbf{5}, 21-31$.

Cunningham MS, Skrastins E, Fitzpatrick R, et al (2015). Cervical cancer screening and human papillomavirus vaccine acceptability among rural and urban women in Kilimanjaro Region, Tanzania. BMJ Open, 5, 1-10.

Degarege A, Krupp K, Fennie K, et al (2018). Original study human papillomavirus vaccine acceptability among parents of adolescent girls in a rural area, Mysore, India. J Pediatr Adolesc Gynecol, 31, 583-91.

Dempsey AF, Zimet GD (2015). Interventions to improve adolescent vaccination. Am J Prev Med, 49, 445-54.

Fernández ME, Le YL, Fernández-espada N, et al (2014). Knowledge, attitudes, and beliefs about human papillomavirus vaccination among Puerto Rican mothers and daughters: a qualitative study. Prev Chronic Dis, 11, 1-8.

Francis SA, Battle-fisher M, Liverpool, J, Hipple L, Mosavel M (2011). A qualitative analysis of South African women's knowledge, attitudes, and beliefs about human papillomavirus and cervical cancer prevention, vaccine awareness and acceptance, and maternal-child communication about sexual health. Vaccine, 29, 8760-5.

Gallagher KE, Lamontagne D, Watson-jones D (2018). Status of human papillomavirus vaccine introduction and barriers to country uptake. Vaccine, 36, 4761-7.

Jaspers L, Budiningsih S, Wolterbeek R, Henderson FC, Peters AA (2011). Parental acceptance of human papillomavirus vaccination in Indonesia: a cross-sectional study. Vaccine, 29, 7785-93.

Karneli NK, Suwiyoga K, Sudibya A(2013). Parental willingness to pay the cervical cancer vaccination cost of senior high school aged students in Badung Regency. PHPM, 1, 70-7.

Masika MM, Ogembo JG, Chabeda SV, Wamai RG, Mugo N (2015). Knowledge on human papillomavirus vaccine and cervical cancer facilitates vaccine acceptability among school teachers in Kitui County, Kenya. PLoS One, 10, 1-14.

Morales-Campos DY, Markham CM, Peskin M (2013). Hispanic mothers and high school girls perceptions of cervical cancer, human papillomavirus, and the human papillomavirus vaccine. J Adolesc Health, 52, 69-75.

Pakasi DT, Kartikawati R (2013). Between needs and taboos: sexuality and reproductive health education for high school students. Makara Seri Kesehatan, 17, 79-87.

Reiter PL, Stubbs B, Panozzo CA, Whitesell D, Brewer NT (2011). Human papillomavirus and human papillomavirus vaccine education intervention: effects on parents, healthcare staff, and school staff. Cancer Epidemiol Biomarkers Prev, 20, 2354-62.

Remes P, Selestine V, Changalucha J, et al (2012). A qualitative study of human papillomavirus vaccine acceptability among health workers, teachers, parents, female pupils, and religious leaders in Northwest Tanzania. Vaccine, 30, 5363-7.

Rosenthal SL, Weiss TW, Zimet GD, et al (2011). Predictors of human papillomaviru vaccine uptake among women aged 19-26: Importance of a physician's recommendation. Vaccine, 29, 890-5.

Sam IC, Wong LP, Rampal S, et al (2009). Maternal acceptance of human papillomavirus vaccine in Malaysia. $J$ Adolesc Health, 44, 610-2.

Whelan NW, Steenbeek A, Martin-Misener R, et al (2014).
Engaging parents and schools improves uptake of the human papillomavirus vaccine: examining the role of the public health nurse. Vaccine, 32, 4665-71.

WHO (2006). Defining sexual health: report of a technical consultation on sexual health. Swiss. WHO Press, pp 10-4.

Wigle J, Coast E, Watson-Jones D (2013). Human papillomavirus vaccine implementation in low and middle-income countries: health system experiences and prospects. Vaccine, 31, 3811-7.

\section{(0) $(\otimes)$}

This work is licensed under a Creative Commons AttributionNon Commercial 4.0 International License. 